УДК 340.143:821.161.9(092)-6

DOI 10.24919/2519-058x.5.118337

Володимир ГАЛИК,

orcid.org/0000-0001-9761-7661

кандидат історичних наук, доцент, докторант кафедри всесвітньої історії та спеціальних історичних дисииллін Дрогобицького державного педагогічного

університету імені Івана Франка

(Україна, Дрогобич) galykvol@ukr.net

\title{
УЧАСТЬ ДРОГОБИЦЬКИХ ЮРИСТІВ ЄВРЕЙСЬКОГО ПОХОДЖЕННЯ У РОЗВ'ЯЗАННІ ОСОБИСТИХ ТА ЮРИДИЧНОМУ ВРЕГУЛЮВАННІ РОДИННИХ ПРОБЛЕМ ІВАНА ФРАНКА (ЗА МАТЕРІАЛАМИ ЛИСТІВ САЛЬО ГАЙНСБЕРГА, ІСААКА ТІГРМАНА ТА ІЗИДОРА ЛЯУТЕРБАХА ДО УКРАЇНСЬКОГО ВЧЕНОГО)
}

\begin{abstract}
Запропоноване дослідження проливає світло на участь дрогобицьких юристів (євреїв за походженням) у процесі розв'язання особистих та юридичного врегулювання деяких родинних проблем Івана Франка упродовж 1887 - 1904 рр. На основі збереженої епістолярної спадщини до I. Франка зазначеного часу вдалося встановити, щзо до кола таких дрогобицьких юристів-помічників входили Сальо Гайнсберг, Ісаак Тітерман та Ізидор Ляутербах. Визначено, шуо листи від дрогобицьких юристів, які адресувалися до вченого з Дрогобича, - це унікальні першоджерела, які передусім дають змогу реконструювати та дослідити малознані факти не лите з життя і багатогранної діяльності Івана Франка, а також докладніше ознайомитися із видами діяльності його дописувачів, невідомими до сьогодні біографічними фактами особистого життя адресантів, які свого часу спілкувалися зі вченим.
\end{abstract}

Ключові слова: Іван Франко, Сальо Гайнсберг, Ісаак Тітерман, Ізидор Ляутербах, дрогобицькі адвокати, епістолярій, юридичне врегулювання проблем, співробітництво.

תim. 21.

Volodymyr HALYK, Ph D (History), Assistant Professor, Doctorant of Department of World History and Special Historical Disciplines, Ivan Franko Drohobych State Pedagogical University (Ukraine,Drohobych)galykvol@ukr.net

\section{PARTICIPATION OF DROHOBYCH LAWYERS OF JEWISH ORIGIN IN THE SOLUTION OF IVAN FRANKO'S PERSONAL AND JURIDICAL REGULATION OF HIS RELATIVES' PROBLEMS (ACCORDING TO THE MATERIALS OF THE LETTERS FROM SALIO GAINSBERG, ISAAC TIGERMANN, AND ISIDOR LAUTERBACH TO THE UKRAINIAN SCHOLAR)}

The suggested investigation clarifies the participation of Drohobych lawyers (of Jewish origin) in the process of solving Franko's personal problems and juridical regulation of the problems of his relatives throughout 1887 - 1904.

On the basis of the survived epistolary heritage of the aforementioned period addressed to Franko the researcher managed to find out that Salio Gainsberg, Isaac Tigermann and Isidor Lauterbach were among such lawyers-assistants from Drohobych who busied themselves with the solution of Franko's problems. Thus, Drohobych barrister Salio Gainsberg, after he had learned from book tradesman Victor Ungar that Franko wished to buy himself an estate in Drohobych, offered him to buy under order his father's estate on the fertile land. To Isaac Tigermann Franko turned for various legal advice and help and it was him that Fanko busied to acquire him a plot of land after he had married his wife who had a good dowry and decided to insert the money into realty. A number of letters from the Drohobych county advocate Isidor Lauterbach tells of how he helped Franko juridically to settle a family conflict in 1902 - 1904, when between Franko's stepfather and brothers a dissention about the inheritance took place.

* Публікація містить результати досліджень, проведених у рамках виконання наукового проекту «Українсько-польсько-єврейські взаємини у Східній Галичині (перша половина XX ст.): історичний досвід, уроки для сучасності», що фінансується за рахунок коштів загального фонду Державного бюджету. ID:95861 29.08.2017 (176-1). 
It is affirmed that the letters from Drohobych lawyers to Franko are unique first-hand sources which allow the researchers to reconstruct and investigate little known facts from Franko's life, his multisided activity, more in detail get acquainted with the activities of his correspondents and unknown hitherto facts from their personal life, especially, which concern their meetings with the writer.

Key words: Ivan Franko, Salio Gainsberg, Isaac Tigermann, Isidor Lauterbach, Drohobych advocates, epistolary, juridical regulation of problems, cooperation.

Ref. 21.

Владимир ГАЛЫК,

кандидат исторических наук, дочент, докторант кафедры всемирной истории и специальных исторических дисциплин Дрогобычского государственного педагогического

университета имени Ивана Франка

(Украина, Дрогобыч) galykvol@ukr.net

\section{УЧАСТИЕ ДРОГОБЫЧСКИХ ЮРИСТОВ ЕВРЕЙСКОГО ПРОИСХОЖДЕНИЯ В РЕШЕНИИ ЛИЧНЫХ И ЮРИДИЧЕСКОМ УРЕГУЛИРОВАНИИ СЕМЕЙНЫХ ПРОБЛЕМ ИВАНА ФРАНКО (ПО МАТЕРИАЛАМ ПИСЕМ САЛЬО ГАЙНСБЕРГА, ИСААКА ТИГЕРМАНА И ИЗИДОРА ЛЯУТЕРБАХА К УКРАИНСКОМУ УЧЕНОМУ)}

Предложенное исследование проливает свет на участие дрогобычских юристов (евреев по происхождению) в проиессе решения личных и юридического урегулирования некоторых семейных проблем Ивана Франко на протяжении 1887 - 1904 г2. На основе сохраненного эпистолярного наследия к И. Франко указанного времени, удалось установить, что в круг таких дрогобычских юристов-помощников входили Салл Гайнсберг, Исаак Титерман и Исидор Ляутербах. Определено, что письма от дрогобычских юристов, которые адресовались к ученому из Дрогобыча, - это уникальные первоисточники, позволяющие прежде всего реконструировать и исследовать малоизвестные факты не только из жизни и многогранной деятельности Ивана Франко, а также подробнее ознакомиться с видами деятельности его авторов, неизвестными до сегодня биографическими фактами личной жсизни адресантов, которые в свое время общались с ученым.

Ключевые слова: Иван Франко, Салл Гайнсберт, Исаак Титерман, Исидор Ляутербах, дрогобычские адвокаты, эпистолярий, юридическое урегулирование проблем, сотрудничество.

Лит. 21.

Постановка проблеми. Важливе місце у сучасному франкознавстві посідає епістолярна спадщина Івана Франка, а особливо збережені листи до нього. Вони слугують багатим джерелом для реконструкції та дослідження не лише життя й багатогранної діяльності письменника, а й його кореспондентів. Зміст цих джерел дає змогу докладніше ознайомитися із біографами Франкових кореспондентів, які сьогодні здебільшого залишаються не вивченими. Також згадані джерела допомагають пізнати історію розвитку та напрями співробітництва I. Франка із колом своїх адресантів, їхніми уподобання, проблеми тощо. 3 огляду на це цікавим, на наш погляд, буде простеження участі дрогобицьких юристів у процесі розв'язання особистих та юридичного врегулювання деяких родинних проблем Івана Франка упродовж $1887-1904$ pp.

Аналіз досліджень. Порушена тут проблема не нова у франкознавстві. Зв'язки Івана Франка з євреями-сучасниками входили до кола зацікавлень багатьох дослідників. Зокрема, Я. Грицак у праці «Пророк у своїй вітчизні. Франко та його спільнота», Франковим контактам $з$ євреями присвятив цілий розділ [3, 335-365]. У 2016 р. вийшла україномовна збірка матеріалів наукової конференції, яка проходила у Віденському університеті 24-25 жовтня 2013 р. «На перехресних стежках. Іван Франко та єврейське питання у Галичині», упорядниками якої стали А. Вольдан та О. Терпіц [14]. До книг увійшли праці знаних франкознавців Р. Мниха, Т. Гундорової, М. Гнатюка, Я. Грицака, Г. Грабовича, А. Вольдана, С. Пшеничного, В. Московича, К. Августиновіча, які через призму фахового аналізу різножанрової творчої спадщини I. Франка, а також характеристики його взаємин із євреями-сучасникам на основі конкретних прикладів «культурного, історичного і біографічного контекстів Фран- 
кової рецепиії єврейського питання» намагаються спростувати звинувачення на адресу українського вченого в антисемітизмі. У передмові до україномовного видання матеріалів згаданого заходу у Віденському університеті, А. Вольдан опротестовуючи юдофобський закид Іванові Франку акцентує на тому, що франкознавці «...змушені звернутися до теми «Франко та єврейське питання», якої дослідники досі торкалися тільки епізодично й стримано: образ великого сина украӥнського народу не міг мати «вразливих місиь». Нерозривно пов'язане з ицим питання украйнсько-єврейських відносин, хоч $і$ виринає з філологічних студій, також далеко виходить поза їх рамки. Із багатовікової традицї̈ співжиття українців та євреїв на території сучасної Украӥни постають також проблеми історичної свідомості в сьогоднішній Україні, осмислення й опрацювання хибних дій і провин у ХХ столітті, ролі єврейства в украӥнській культурі. Приклад Івана франка, украӥнця із старої Галичини, який жив в одному з євреями політичному, соціяльному та культурному просторі, засвідчує різні виміри изього співжиття у надзвичайно показовий спосіб» [14, 8-9].

Побіжно скажемо, що тема листування Сальо Гайнсберга, Ісаака Тігермана та Ізидора Ляутербаха з Іваном Франко була предметом і нашого зацікавлення. Зокрема, у процесі публікації усієї збереженої епістолярної спадщини до І. Франка, відправленої із поштової скриньки Дрогобича, нами вперше було опубліковано листи згаданих Франкових кореспондентів (видано листи польською мовою та здійснено україномовний переклад) із супровідним коментарем до них [1, 82-102, 212-219].

3 огляду на вищесказане ставимо собі за мету максимально глибоко проаналізувати збережені листи до Івана Франка від дрогобицьких юристів-євреїв (Сальо Гайнсберга, Ісаака Тігермана та Ізидора Ляутербаха), які безпосередньо допомагали Франкові розв'язувати як особисті проблеми, так і юридично врегульовувати деякі родинні спірні питання, з котрими вчений стикався впродовж $1887-1904$ рр.

Виклад основного матеріалу. 5 червня 1887 р. Іван Франко одержав листа від дрогобицького адвоката Сальо Гайнсберга, в якому автор, дізнавшись від дрогобицького книгаря Унгара Віктора* про те, що вчений хоче купити собі господарство в Дрогобичі, пропонував йому на продаж під замовлення двір на родючій землі свого батька [5]. На цей лист I. Франко відповіді не дав.

Частим дописувачем до Івана Франка був Ізидор (Ігнацій) (Ісаак) Тігерман, який працював адвокатом у Дрогобичі. Також він був гімназійним товаришем Івана Франка - закінчив iii разом 3 I. Франком у 1875 р. (з I. Тігерманом І. Франко вчився і в нормальній школі отців Василіян). Часто користувався іменами-псевдонімами Ігнацій та Ізидор, які уживав, мабуть, щоб приховати своє єврейське походження, оскільки в цей час в Дрогобичі входила «Gazeta Naddniestrzacska», яка була конкурентом часопису «Drohobyczer Zeitung», що представляла інтереси єврейської еліти. «Gazeta Naddniestrzacska» оголосила себе голосом соціал-національної опозиції $[15,111]$, i, можливо, тому І. Тігерман підписувався під різними іменами (3 метою запобігання антиреклами), проте не змінював прізвище.

У контексті зазначимо, що ще у 1884 р. І. Франко отримав листівку від свого товариша П. Мельника***, зміст якої деякою мірою дає уявлення про Франкові відносини із родиною

\footnotetext{
* Віктор Унгар - книгар у Дрогобичі, привозив Іванові Франкові замовлені ним книжки зі Львова.

** Панас (Атанас) Мельник - (14 липня 1857 р. - 24 квітня 1905 р.) - родом із Волі Якубової. У 1883 р. внаслідок перевороту у читальні, який вчинили його прихильники, став її головою та виключив з неї сімох своїх опонентів. Мельник звинуватив стару владу у зловживанні громадськими грошима. На виборах 1884 p. його партія здобула більшість у сільській раді (10 із 18 радників), а 1885 р. йому не вистачило одного голосу, щоб обратися на посаду сільського війта. Він закінчив дяківську школу в Перемишлі. Його зусиллями та за підтримки графа Тарнавського зі Снятинки за рішенням Дрогобицького повітового виділу було збудовано биту (шутровану) дорогу з Дрогобича до Волі Якубової завдовжки 9 км. Атанас Мельник викупив корчму і побудував з неї громадський дім - радницю, у якому разом з парохом села о. Никифором Лещищаком заснував читальню товариства «Просвіта». За «бунтування селян» був засуджений австрійським судом. За деякими твердженнями у тюрмі в Самборі він захворів на сухоти, які передчасно у 1905 році звели його в могилу на 48-му році життя. В Атанаса Мельника народився син, якого назвали Андрієм. Він пішов тою ж стежкою, що й батько, і у 1940 р. став провідником Організації українських націоналістів.
} 
Автограф листа Сальо Гайнсберга до Івана Франка від 05 червня 1887 р. зм. Дрогобича

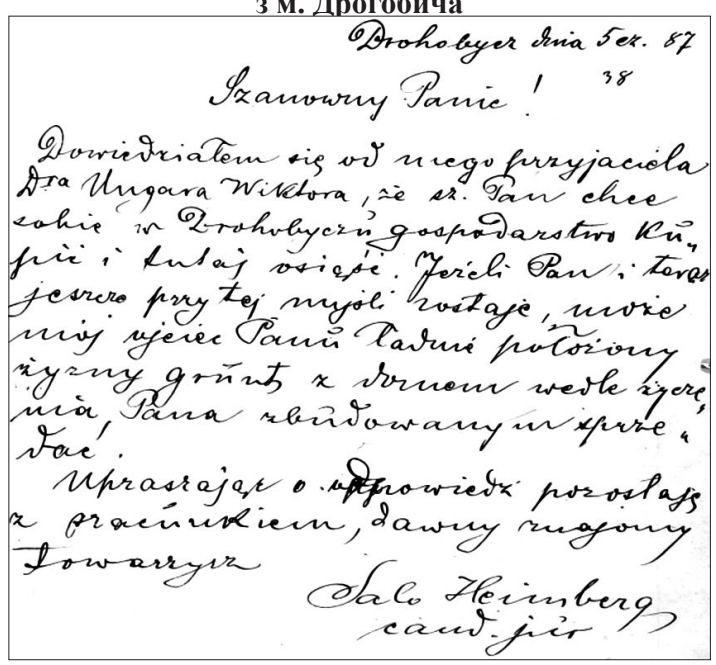

Подається за:

І. Л. - Ф. 3. - Од. збр. 1602. - С. 97.
Тігерманів. Отже, згаданий адресант розповідає, що «Дуже жалував Тігерман старий шуо неміг з Вами видітись, так просит Вас а щоби зробилисьте му тойе ощо він Вас просив т.є. (що до йего доньки - щобисьте поговорили ским належит ... аби тійі йей непсували - $i$ щоби она добру клясу дістала» [13]. Про цю ж проблему писав від 21 червня 1884 p. I. Франку згадуваний уже Віктор Унгар, і теж повідомляв, що «Ізидор Тігерман, доручивщи звернутися до Вас і просити Вашого втручання в справу його сестри n. Антоніни Тігерман, учениці учительської семінаріі. Точніше, йдеться тут про Професорів Бічая і Партицького, які нібито небезсторонньо ставляться до неї» [20].

Таким чином, у вищезгаданих листах до I. Франка мова йде про сестру I. Тігермана Антоніну Тігерман, котра навчалась у Львівській жіночій учительській семінарії. Саме в гімназії два вчителі погрожували їй поганою оцінкою з поведінки. Тому І. Тігермам із вітчимом звернулись за допомогою до I. Франка, тому що в тій семінарії вчителювали чимало його добрих знайомих. Одним із таких був Омелян Огоновський - друкував із I. Франком свої твори у журналі «Зоря», та ще один знайомий - вчитель математики Іван Бічай. Саме до них просили звернутися за допомогою Ісаак Тігерман та його вітчим Ківа Тігерман. Справа, очевидно, була полагоджена, бо Антоніна успішно закінчила семінарію в 1886 р., а опісля працювала вчителькою в Дрогобичі, однак невдовзі померла [2, 268; 16; 19].

Батьком I. Тігермана був Ліпе Тігерман - писар, а мати - Майле Розенберг. Проживали Tiгермани в центральній частині Дрогобича в будинку під № 38. I. Тігерман навчався на юридичному факультеті Віденського університету, після закінчення якого практикувався у різних адвокатських конторах. 9 лютого 1885 р. Ісаак Тігерман повідомляе Івана Франка, що секретар, не знаючи його, не вручив йому паспорт вченого, а відправив його на адресу I. Франка [17]. Після закінчення віденського університету (1886) І. Тігерман склав два кваліфікаційні екзамени $з$ права і отримав ступінь доктора та право на самостійну адвокатську практику. У 1890 р. приступив до урядової роботи в Дрогобицькому суді. У 1894 р. залишив державну службу і відкрив самостійну адвокатську контору в Добромилі [2, 238, 268-269].

До I. Тігермана часто звертався I. Франко за різними адвокатськими порадами та допомогою. Саме йому він доручив придбати для себе якийсь «кусок трунту» після того, як отримав посаг за дружиною і вирішив одержані гроші вкласти в нерухомість. Від людей Іван Франко дізнався, що продається земля в Унятичах, які сусідують з Нагуєвичами, і тому про-

Автограф листівки Ісаак Тігермана до Івана Франка від 9 лютого 1885 р. із Дрогобича.

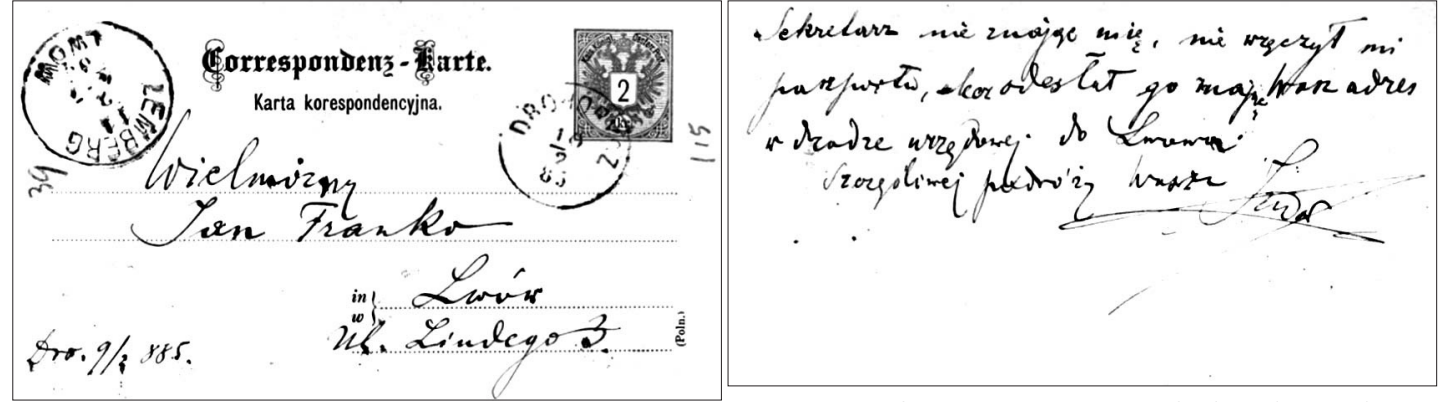

Подається за: І. Л. - Ф. З. - Од. зб. 1615. - С. 115-116. 
сив I. Тігермана зайнятися цією справою. Справа з купівлі землі тягнулась до 1890 р., проте власник землі Гофрат Крейсберг відмовився її продавати, про що дізнаємося з листа I. Тігермана від 12 січня 1895 р. [2, 269-271; 18] Саме завдяки I. Тігерману I. Франко був врятований від фізичної розправи агентів пана Павла Тишковського, який був суперником I. Франка на виборах у 1895 р. [Див. про це у: 21]

Чимало листів збереглося від крайового адвоката з міста Дрогобича Ізидора Ляутербаха, який юридично допомагав I. Франкові протягом 1902 - 1904 рр., коли між вітчимом і братами Франками виникла суперечка за спадщину. Сварка в родині розпочалася через Марію Гаврилик (народилася в 1881 р.), дочку в третьому шлюбі Григорія Гаврилика і вдови Петра Франка Параски Франко. Брати вважали, що Г. Гаврилик віддасть увесь маєток Марії, а вони втратять спадщину. Сварка закінчилася судовим процесом, який тривав з 1902 до 1904 рр. За рішенням суду грунт було розділено між Франками і Гавриликами. Захар Франко залишився проживати у збудованій хаті. Сам Г. Гаврилик збудував собі хату ближче до потока, а Онуфрій купив грунт і садибу в Підгірцях біля Калуша [2, $68 ; 4,31]$.

14 грудня 1902 р. Ізидор Ляутербах повідомляє Івана Франка, що той повинен приїхати до Дрогобича 16 грудня цього року, оскільки має бути підписана угода братів з родиною вітчима Григорія Гаврилика. Але, якщо угода буде зірвана, то приїзд Івана Франка є необов'язковим [9]. У наступному листі від 3 листопада 1903 р. І. Ляутербах повідомляє вченого, що Г. Гаврилик подав апеляційне звернення щодо розриву співвласності на маєток в Нагуєвичах, наслідком якого $є$ призначення нового апеляційного засідання в окружному суді Самбора, яке відбудеться 11 листопада 1903 р. о 10 годині [11]. Зразу ж після апеляційного засідання I. Ляутербах пише: «...nовідомляю, що після вручення мені вироку другої інстанщії, а це настане лише за пару тижнів, проведу екзекуизію (юридичні дії - В. Г.), а про термін ліųитації (аукціону - В. Г.) В[исокомановного] Пана повідомлю» [10].

Майже через три місяці І. Ляутербах знову звертається до Івана Франка. У листі автор розказує, що схилив його брата Захара до спокою у справі переділу майна і тепер родина має три місяці для позасудового врегулювання тієї суперечки. Для задоволення претензій Захара, йому запропоновано «париелі (наділи землі - В. Г.), звані «на валу», означені 11 кат. гр. 9196, 9219/1, 9216, 9165 площею 17 га. 73 м. і частину бад. 351 довкола старої хати...». Проте Захар з цим рішенням не погоджувався і уперто вимагав ще земельних наділів «...9319 і 9318, званих «на загальнім», або «на короткім», площею 24 га. 10 м.». I. Ляутербах також пропонує I. Франку, щоб при розподілі маєтку між Г. Гавриликом і Захаром Франком також за одним коштом і заходом виділили частку й Онуфрієві, і це треба зробити навесні, доки почнуться роботи. Також адвокат радить про всяк випадок подати зустрічний позов проти Г. Гаврилика, оскільки за рішенням не можна буде продати нагуєвицьку власність [7]. 
Автограф листа (рукопису)

Ізидора Ляутербаха до Івана Франка від 16 листопада [19]03 р. із Дрогобича.

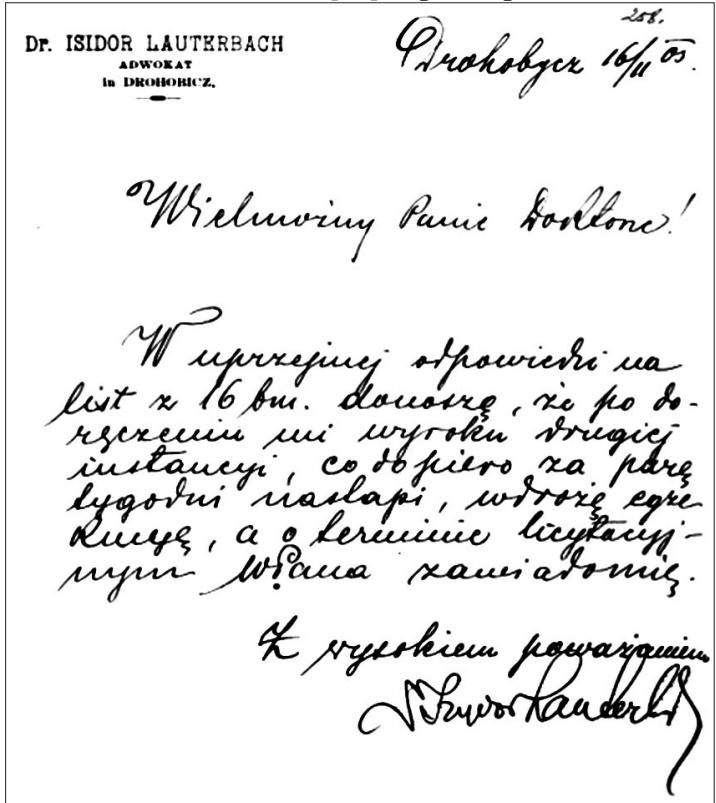

Wo an

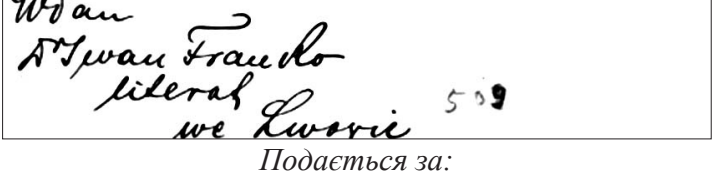

І. Л. -Ф. 3. - Од. зб. 1624. - С. 509.
У листі від 7 березня 1904 р. адвокат повідомляє вченого, що примирення між родиною Франків та Гавриликів майже близько, i радить йому оформити генеральне й необмежене уповноваження для його брата Онуфрія, оскільки Іван Франко хотів передати йому свою частку майна [12]. Через п’ять днів I. Ляутербах відсилає I. Франкові акт поділу майна між родиною Франків та Гавриликів. В пункті «А» вказується, що "[він] укладений згідно з вказівками $і$ за згодою Вашого брата Онуфрія, думаю, що відповідає і Вамій волі. Прошу підписати його $i$ підпис в суді чи в нотаріуса легалізувати ...». Також у контракті ухвалено, «щяо належні Вам від Гриня Гаврилика і Захара суми купівлі (500 кор. $і 1120$ кор.) можуть бути виплачені Вам $і$ братові Онуфрію через інтабуляцію права застави нерухомого майна боржників. Якщз Ви вважаєте їхні зобов'язання гідними довіри, можна не застосовувати право застави $i$ зекономити собі і їм кошти, котрі, як-не-як, складають кільканадиять корон». Другий пункт договору «B» Іван Франко повинен підписати в нотаріуса або легалізувати в суді. В кінці листа автор наголошує, що це повноваження, яке вчений склав для брата Онуфрія є дуже широким, тому він залишає його зміст на розсуд I. Франка: «чи не належало б його обмежити; це залежить внутрімніх стосунків поміж вами і братом Онуфрієм, які не підлягають критиці юриста» [8].

Щодо цієї теми, то зберігся ще один лист авторства Володимира Йойка, судді, який, напевне, вів справу Івана Франка та його родини в 1902 - 1904 рр., пов'язану із суперечкою за спадщину з вітчимом Григорієм Гавриликом. В. Йойко пише: «...не відписував Вам, бо гадав, щчо Ваша Родина зголосит ся (звернеться - В. Г.) до мене, та хот [i]в Вам доперва (спершу B. Г.) по полагодженю справи дати знати щзо $і$ як, коли однак Вамі не [проти] [сего] - то прошу зарядити (повідомити - В. Г.), щеб явились у мене в суд[i], мен[i] розтолкували, о щзо їм ходити [потрібно], а я стану йіi]лий [д]ухом, тай старатись му всьо як сьл[і]д по закону зробити ...» [6]. Процитовані з листа слова В. Йойка, є свідченням того, що Іван Франко заручався не лише підтримкою адвокатів, але й суддів, щоб позитивно розв'язати проблему майнового конфлікту для своєї родини.

Висновки. У ході проведеного аналізу епістолярію від Сальо Гайнсберга, Ісаака Тігермана та Ізидора Ляутербаха з Іваном Франком бачимо, що між ними існували приязні стосунки. Зі змісту збережених листів чітко видно, що адресанти невимушено сприяли І. Франкові розв'язувати як приватні справи, так і юридично врегульовувати певні родові конфліктні проблеми, 3 якими вчений стикався упродовж 1887 - 1904 рр. Проте подані тут сюжети Франкових відносин з єврейською спільнотою далеко не повністю розкривають ті його двосторонні приязні взаємини. $€$ ще чимало збережених листів від євреїв різних соціальних категорій до I. Франка, вивчення яких дало б можливість більш повно та різнопланово проаналізувати зв'язки вченого із ними. Тому перспективним, на наш погляд, залишається подальше прискіпливе вивчення епістолярної спадщини I. Франка. 


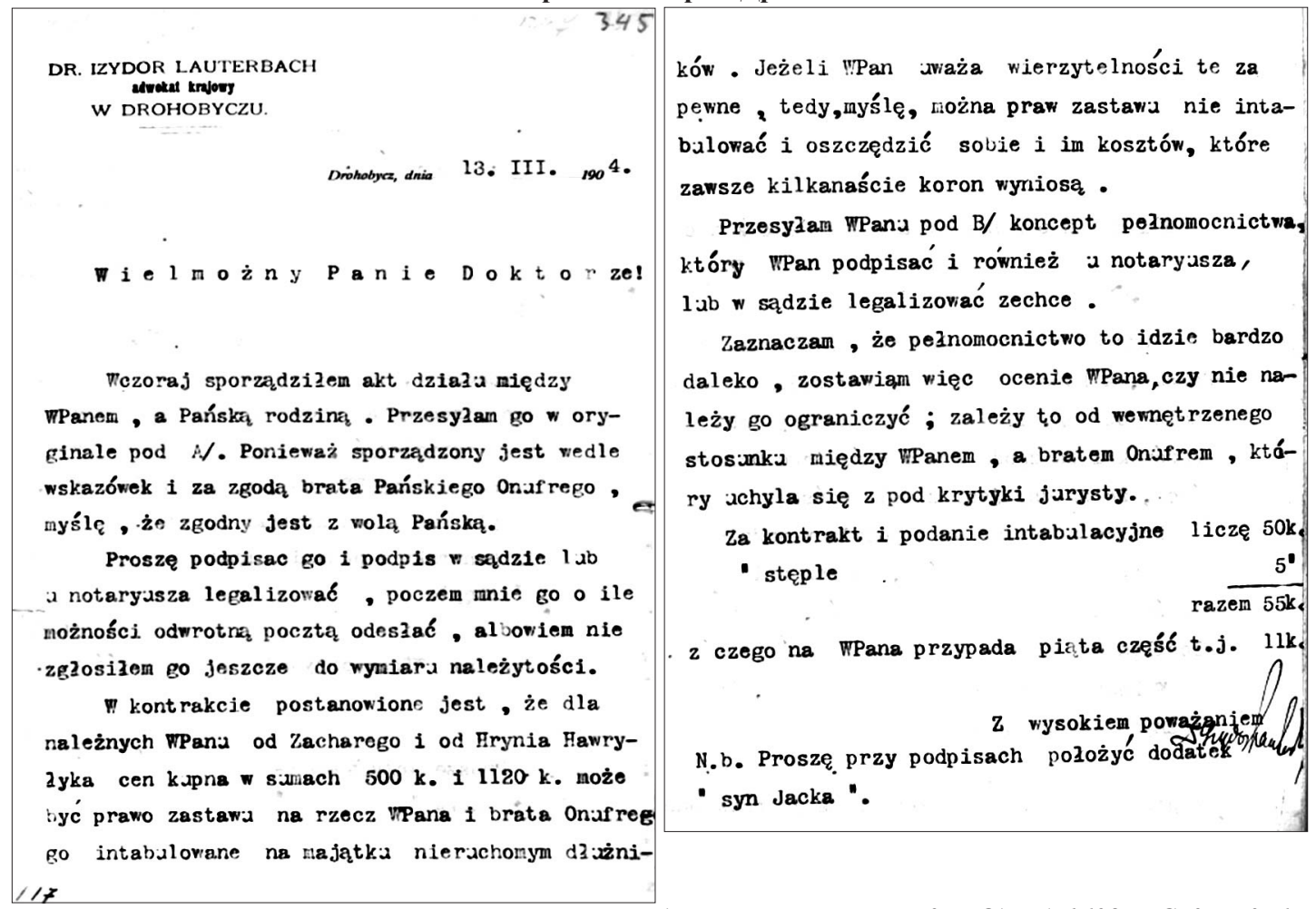

Подається за: І. Л. - Ф. 3. - Од. зб. 1638. - С. 345-346.

\section{СПИСОК ВИКОРИСТАНИХ ДЖЕРЕЛ І ЛІТЕРАТУРИ}

1. Адресати з Дрогобича до Івана Франка / Упорядкування, передмова і коментарі Володимира Галика / Наук. ред. Леонід Тимошенко. - Дрогобич: Коло, 2011. - 308 с.

2. Горак Р. Іван Франко / Р. Горак, Я. Гнатів. - Львів: Видавництво отців Василіян «Місіонер», 2002. Кн. третя. Гімназія. -360 с.

3. Грицак Я. Пророк у своій вітчизні. Франко та його спільнота $(1856-1886)$ / Я. Грицак. - К.: Критика, 2006. $-632 \mathrm{c}$.

4. Гром Г. Нагуєвичі / Г. Гром. - Дрогобич: «Відродження», 2002. - 288 c.

5. Гайнсберг С. Лист до І. Франка від 5 червня 1887 р. $з$ м. Дрогобича / С. Гайнсберг. - І. Л. - Ф. 3. Од. збр. 1602. - С. 97.

6. Іойко (Йойко) Володимир. Лист до І. Франка від 15 грудня 1903 р. $з$ м. Дрогобича / Володимир Іойко (Йойко). - І. Л. - Ф. 3. - Од. збр. 1630. - С. 370-371.

7. Ляутербах Ізидор. Лист до I. Франка від 11 лютого 1904 р. з м. Дрогобича / Ізидор Ляутербах. І. Л. - Ф. 3. - Спр. 1638. - С. 343-344.

8. Ляутербах Ізидор. Лист до І. Франка від 13 березня 1904 р. 3 м. Дрогобича / Ізидор Ляутербах. І. Л. - Ф. 3. - Спр. 1638. - С. 345-346.

9. Ляутербах Ізидор. Лист до І. Франка від 14 грудня 1902 р. 3 м. Дрогобича / Ізидор Ляутербах. І. Л. - Ф. 3. - Од. збр. 1624. - С. 329-330.

10. Ляутербах Ізидор. Лист до І. Франка від 16 листопада 1903 р. з м. Дрогобича / Ізидор Ляутербах. І. Л. - Ф. 3. - Од. збр. 1624. - С. 509.

11. Ляутербах Ізидор. Лист до І. Франка від 3 листопада 1903 р. $з$ м. Дрогобича / Ізидор Ляутербах. І. Л. - Ф. 3. - Од. збр. 1624. - С. 505-506.

12. Ляутербах Ізидор. Лист до I. Франка від 7 березня 1904 р. 3 м. Дрогобича / Ізидор Ляутербах. І. Л. - Ф. 3. - Спр. 1624. - С. 555-558.

13. Мельник Панас [Атанас]. Листівка до І. Франка від 1884 р. з м. Дрогобича / Панас [Атанас] Мельник. - І. Л. - Ф. 3. - Од. збр. 1615. - С. 561-562. 
14. На перехресних стежках: Іван Франко та єврейське питання у Галичині. Матеріяли наукової конференції у Віденському університеті (24-25 жовтня 2013 року) / Упоряд. Алоїз Вольдан, Олаф Терпіц. К.: Критика, 2016. - 184 с.

15. Нариси з історії Дрогобича (від найдавніших часів до початку XXI ст.) / ДДПУ ім. І. Франка, істор. факультет / Наук. ред. Л. Тимошенко. - Дрогобич: Коло, 2009. - 320 с.

16. [Тігерман Ізидор]. Листівка до І. Франка від 22 червня 1884 р. 3 м. Відня . - I. Л. - Ф. 3. Од. збр. 1618. - С. 515-516.

17. [Тігерман Ізидор]. Листівка до І. Франка від 9 лютого 1885 р. 3 м. Дрогобича. - I. Л. - Ф. 3. Од. збр. - 1615. - С. 115-116.

18. Тігерман Ізидор. Лист до І. Франка від 12 січня 1890 р. 3 м. Дрогобича / Ізидор Тігерман. - I. Л. Ф. 3. - Од. збр. 1605. - С. 409.

19. [Тігерман Ківа]. Лист до І. Франка від 22 червня 1884 р. - І. Л. - Ф. 3. - Од. збр. 1618. - С. 209.

20. [Унгар Віктор]. Лист до І. Франка від 21 червня 1884 р. $з$ м. Дрогобича. - І. Л. - Ф. 3. - Од. збр. 1618. C. 517-518.

21. Франко I. Найновіший галицький вибір / I. Франко // Франко I. Зібрання творів у 50-ти т. + додаткові томи. - К.: Наукова думка, 1986. - Т. 46. - Кн. 2. - С. 280-291.

\section{REFERENCES}

1. Adresaty z Drohobycha do Ivana Franka / Uporiadkuvannia, peredmova i komentari Volodymyra Halyka / Nauk. red. Leonid Tymoshenko. - Drohobych: Kolo, 2011. - 308 s.

2. Horak R. Ivan Franko / R. Horak, Ya. Hnativ. - Lviv: Vydavnytstvo ottsiv Vasyliian «Misioner», 2002. Kn. tretia. Himnaziia. - $360 \mathrm{~s}$.

3. Hrytsak Ya. Prorok u svoii vitchyzni. Franko ta yoho spilnota (1856-1886) / Ya. Hrytsak. - K.: Krytyka, 2006. $-632 \mathrm{~s}$

4. Hrom H. Nahuievychi / H. Hrom. - Drohobych: «Vidrodzhennia», 2002. - 288 s.

5. Gainsberg S. Lyst do I. Franka vid 5 chervnia 1887 r. z m. Drohobycha / S. Gainsberg. - I. L. - F. 3. Od. zbr. 1602. - S. 97.

6. Ioiko (Ioiko) Volodymyr. Lyst do I. Franka vid 15 hrudnia 1903 r. z m. Drohobycha / Volodymyr Ioiko (Ioiko). - I. L. - F. 3. - Od. zbr. 1630. - S. 370-371.

7. Liauterbakh Izydor. Lyst do I. Franka vid 11 liutoho 1904 r. z m. Drohobycha / Izydor Liauterbakh. I. L. - F. 3. - Spr. 1638. - S. 343-344.

8. Liauterbakh Izydor. Lyst do I. Franka vid 13 bereznia 1904 r. z m. Drohobycha / Izydor Liauterbakh. I. L. - F. 3. - Spr. 1638. - S. 345-346.

9. Liauterbakh Izydor. Lyst do I. Franka vid 14 hrudnia 1902 r. z m. Drohobycha / Izydor Liauterbakh. I. L. - F. 3. - Od. zbr. 1624. - S. 329-330.

10. Liauterbakh Izydor. Lyst do I. Franka vid 16 lystopada 1903 r. z m. Drohobycha / Izydor Liauterbakh. I. L. - F. 3. - Od. zbr. 1624. - S. 509.

11. Liauterbakh Izydor. Lyst do I. Franka vid 3 lystopada 1903 r. z m. Drohobycha / Izydor Liauterbakh. I. L. - F. 3. - Od. zbr. 1624. - S. 505-506.

12. Liauterbakh Izydor. Lyst do I. Franka vid 7 bereznia 1904 r. z m. Drohobycha / Izydor Liauterbakh. I. L. - F. 3. - Spr. 1624. - S. 555-558.

13. Melnyk Panas [Atanas]. Lystivka do I. Franka vid 1884 r. z m. Drohobycha / Panas [Atanas] Melnyk. I. L. - F. 3. - Od. zbr. 1615. - S. 561-562.

14. Na perekhresnykh stezhkakh: Ivan Franko ta yevreiske pytannia u Halychyni. Materiialy naukovoi konferentsii u Videnskomu universyteti (24-25 zhovtnia 2013 roku) / Uporiad. Aloiz Voldan, Olaf Terpits. - K.: Krytyka, 2016. - 184 s.

15. Narysy z istorii Drohobycha (vid naidavnishykh chasiv do pochatku KhKhI st.) / DDPU im. I. Franka, istor. fakultet / Nauk. red. L. Tymoshenko. - Drohobych: Kolo, 2009. - 320 s.

16. [Tiherman Izydor]. Lystivka do I. Franka vid 22 chervnia 1884 r. z m. Vidnia . - I. L. - F. 3. - Od. zbr. 1618. - S. 515-516.

17. [Tigerman Izydor]. Lystivka do I. Franka vid 9 liutoho 1885 r. z m. Drohobycha. - I. L. - F. 3. - Od. zbr. 1615. - S. 115-116.

18. Tiherman Izydor. Lyst do I. Franka vid 12 sichnia 1890 r. z m. Drohobycha / Izydor Tiherman. - I. L. F. 3. - Od. zbr. 1605. - S. 409.

19. [Tiherman Kiva]. Lyst do I. Franka vid 22 chervnia 1884 r. - I. L. - F. 3. - Od. zbr. 1618. - S. 209.

20. [Ungar Viktor]. Lyst do I. Franka vid 21 chervnia 1884 r. z m. Drohobycha. - I. L. - F. 3. - Od. zbr. 1618. S. 517-518.

21. Franko I. Nainovishyi halytskyi vybir / I. Franko // Franko I. Zibrannia tvoriv u 50-ty t. + dodatkovi tomy. - K.: Naukova dumka, 1986. - T. 46. - Kn. 2. - S. 280-291.

Стаття надійила до редакичї 30.10.2017 p. 